\title{
Rita Angus: A New Madonna 1942-1951
}

Susannah Whaley

This article explores the 'New Madonna' in Rita Angus's artwork in the 1940s and early 1950s. The New Madonna combines female independence and celibacy with sexuality and motherhood. She develops from Angus's position as a woman painter who lived and worked alone, and is expressed in three nudes and a number of goddess portraits which are discussed. The origins of the term 'New Madonna' and the interpretative possibilities it affords to Angus's art are examined. These works allow Angus to inscribe herself with a value derived from being female. In order to offer insight into these portraits, Angus's letters to the composer Douglas Gordon Lilburn are considered. 


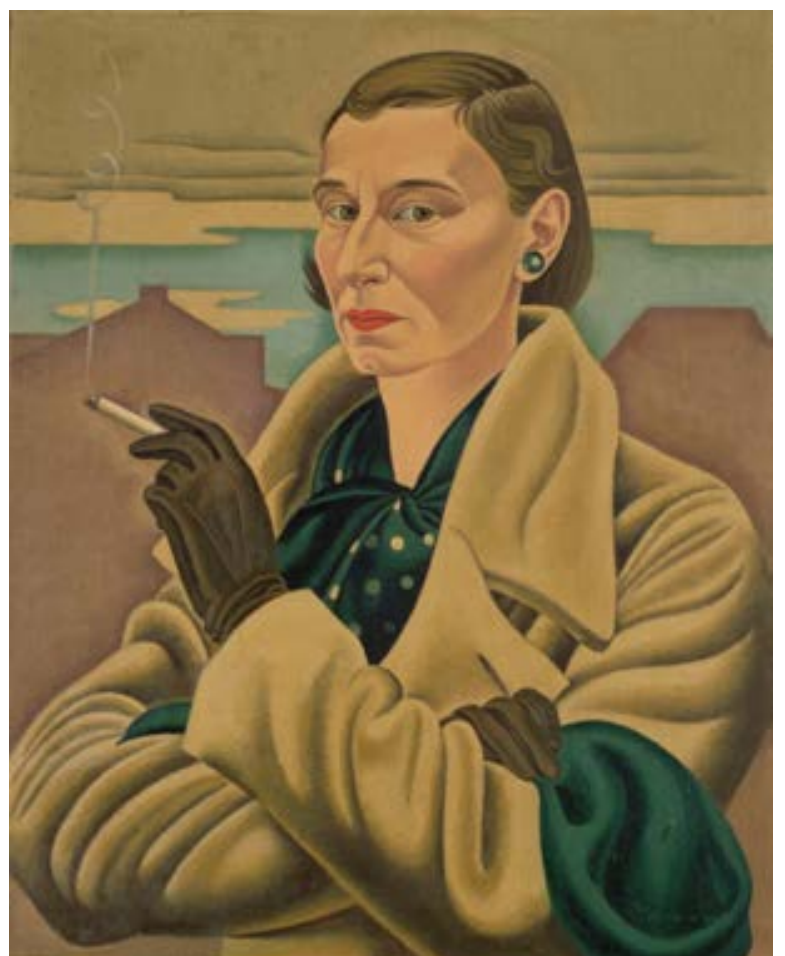

Self-Portrait (1936-1937) is one of the most well known images of Rita Angus, completed during her separation from the artist Alfred Cook. She smokes a cigarette with her arms crossed across the front of her body and wears an oversized coat much like a man's, asserting her own sufficiency. As a woman, an artist, and a divorcee, Angus's art and art practice challenges mid-twentieth-century New Zealand gender normalities. During the years after her separation in 1934 until her divorce, and even afterwards, Angus was neither "maid, wife, nor widow", nor mother, an uncommon position in a society that valued women by their affective connection to men. In 1924, when Angus was 16, Ladies' Mirror columnist V. Quirk implied that there were four types of women only: "the spinster, the mother-woman, the wifewoman, and most rare, the wife-and-mother woman". Each woman was defined by her love (or lack thereof) towards a husband or child. By contrast, in Self-Portrait Angus embodies the early twentieth-century "new woman". In a collection of essays on art and gender in Australia, academic Pamela Niehoff defines this "new woman" by describing women going out to work, women obtaining university degrees, and housewives with leisure time, women such as Grace Crowley's Portrait of Lucie Beynis (1929) and Sybil Craig's Peggy (1932). Lucie Beynis shows an intellectual woman with a book, short hair, and a businesslike costume, and Niehoff comments that "[t]he direction of the model and her gaze suggest preoccupation with her own thoughts". Peggy smokes and the "closeness of the image to the picture plane... enhances Peggy's confidence in her own appearance, not sitting but 'on the move'". Likewise, in Angus's Self-Portrait, her upper body fills the frame and her gaze is self-assured. The portrait places Angus within the international trend of women painters imaging a new woman. However, this is a woman who largely remained out of place in Angus's daily world.

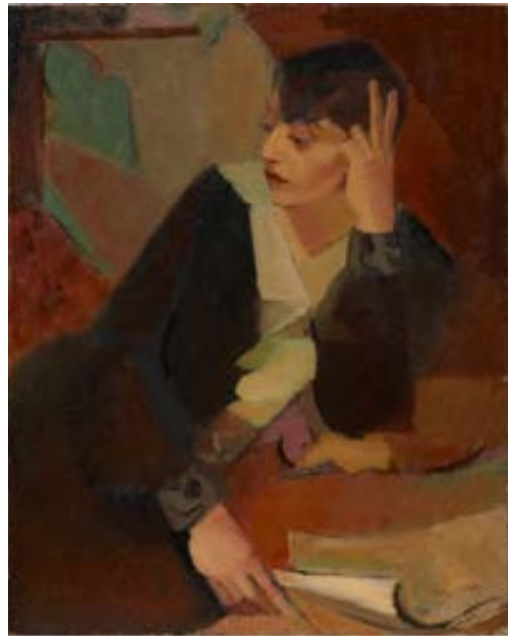

Grace Crowley. Portrait of Lucie Beynis (1929). Oil on canvas on hardboard, 797 $\times 645$. Art Gallery of New South Wales, purchased 1965, OA14.1965

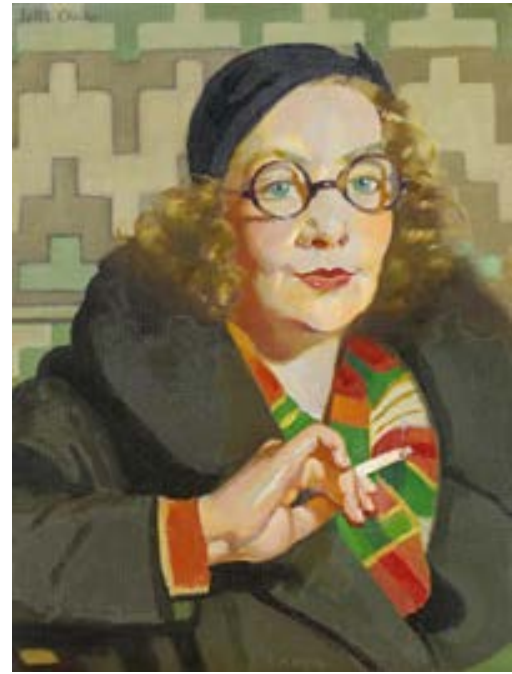

Sybil Craig. Peggy (1932). Oil on canvas, 404 × 304. National Gallery of Victoria, Melbourne, purchased 1978, A3-1978. $\odot$ Estate of Sybil Craig
A new image of female independence appears in Angus's work in the following decade. Angus's paintings and the image she crafted of herself as a painter in the 1940s gave rise to what she herself called the 'New Madonna'. Crucial to the understanding of Angus's art are her letters to the composer Douglas Gordon Lilburn, in which she discusses the effects on her art of her miscarriage in 1942, and her subsequent 
renegotiation of her sexuality and her relationship with Lilburn.

Lilburn was the father of Angus's child and also homosexual, though whether Angus knew this in the 1940s or later is unclear. Angus writes to him in 1944 that she hears herself being exalted in his composition Magnificat and Nunc Dimmitis. This piece shows a "glimpse of the new Madonna" who "was born [...] of a woman pacifist who worked among conscientious objectors in a Pacifist co-op, in Wellington". The New Madonna develops through Angus's lifestyle as a woman painter who lived and worked in isolation, as well as through a new woman she creates in her portraits, and particularly her goddess portraits. She arises from traditional imagery of the Christian Mary as Virgin Mother of God, but differs from her in important ways. While apparently chaste, this new female figure embraces her womanhood and her creative capabilities. The portraits and self-images that Angus worked on in this decade highlight female independence, while concomitantly acknowledging female sexuality.

Both Jill Trevelyan in her biography Rita Angus: An Artist's Life (2008) and, more extensively, Bronwyn Lloyd in her PhD thesis "Daemons and Dream Children" (2009), have acknowledged Angus's goddess portraits in particular as imaging a "New Madonna". Trevelyan contends that the goddess paintings "update" a Western tradition of Madonnas in the Pacific. Lloyd states of Angus's goddess portrait Rutu: "Angus's interest [was] in the concept of a twentieth century pacifist Madonna and child, heralding a second coming and bringing a message of peace and hope to a war-torn modern world". However, it remains to focus and develop this image, particularly in the context of Angus herself. In the 1940s, Angus was living as a single woman. According to social norms, she had failed as a wife and a mother. Moreover, as her child was conceived illegitimately and Lilburn refused her wish for another child or further intimacy, this meant that her grief was mostly private, as only a few close friends knew of her pregnancy. She frequently discusses her child in her letters to Lilburn, but the portraits themselves are heavily imbued with symbolism. Representation of Angus's personal life in her art recalls Mexican artist Frida Kahlo's (1907-1954) Henry Ford Hospital (1932), where Kahlo's miscarriage is represented by symbols. Kahlo presents herself naked on a hospital bed with symbols of her loss, such as a fractured pelvis and a foetus, floating around her. Angus's miscarriage a decade later takes shape in paint far more subtly, likely due to the child's illegitimacy, but also to the isolated and still puritanical New Zealand society in which she lived. Without her letters, which contained information about her portraits not made public, there would be no way to offer the interpretative possibilities that this essay does. The Madonna, as an ideal symbol of motherhood, is an apt, and in hindsight even a provocative persona for Angus to choose as she negotiated a new motherhood to her art, taking possession of her female sexuality, whether or not she was physically a mother.

I focus on three nudes and a number of goddess portraits, including little-discussed watercolour sketches. In these pictures, independence is conveyed, but it is a differently negotiated image than that of the woman in the trench coat - this new woman is the "New Madonna". Of the other female figures appearing in New Zealand art at this time, similarities can be drawn between Angus's goddesses and Lois White's corporeal goddess figure in her portrait Ode to Autumn (1945). However, being able to chart Angus's back story of the New Madonna through her letters show the unique image of womanhood she created was unlike that with which women in New Zealand are known to have experimented with at the time. As well as important personal images, the goddesses are forerunners to Robyn Kahukiwa's Hinetitama (1980) as wāhine toa. The "New Madonna" becomes an increasingly important trope in Angus's art and in her selfmythologising as a painter through the 1940s, one which reinscribes her with a value derived from being female.

\section{SUBLIMATING AND SANCTIFYING}

In July 1942 Angus describes drawing herself in the nude and states that "the child would have been born in about two weeks". These nudes develop a sexual but unusual image of her naked body. Breasts and hips indicate childbearing, yet the woman stands alone. The drawings accentuate her figure curving in where it should curve out. The standing pencil sketch shows the hollowed cavity below her ribs, her narrow waist, arms spread wide rather than brought to the body to hold a baby. However, following this apparent acknowledgement of loss, the drawings can be seen to express recovery. Lloyd calls them a "narrative sequence". Angus shows her own face inclining towards the viewer, or towards herself as the artist, indicating she is able to meet her own gaze with confidence. In the seated nude, the gaze is partially hidden by the tilt of her face and her seated pose positions her further away. 


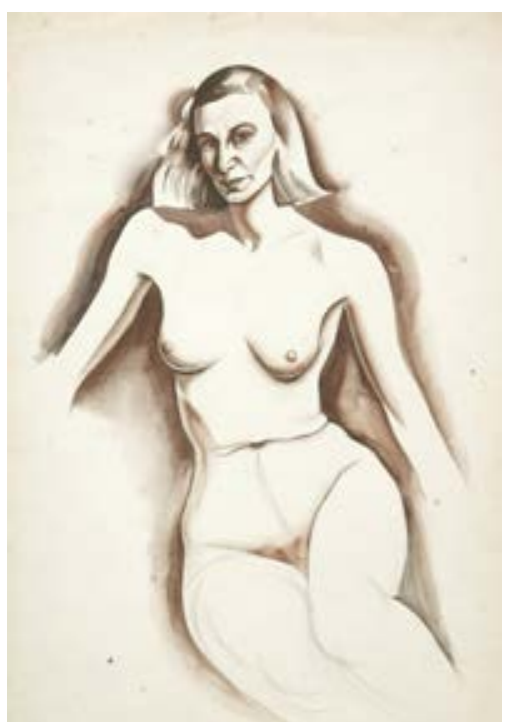

Rita Angus. Self-portrait (nude, seated) (c. 1942). Pencil and wash T23 $\times 286$. Museum or New Zealand loan from the Rita Angus Estate

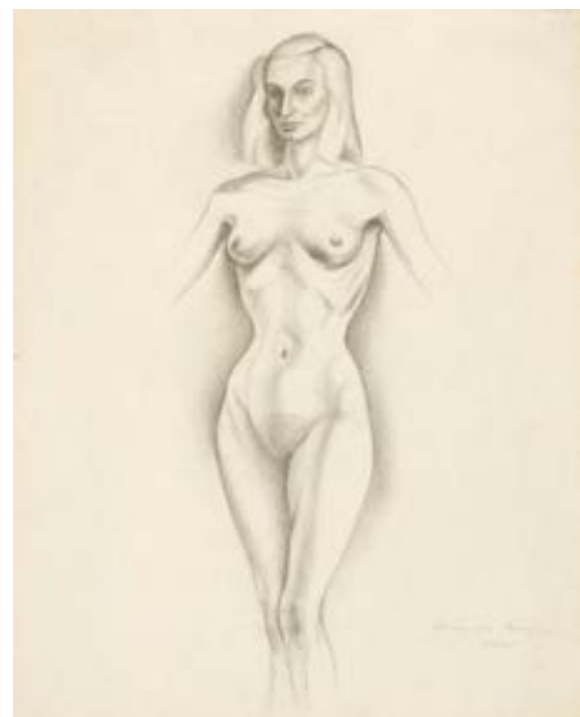

Rita Angus. Study for carving tors (nude self portrait) (c. 1942). Pencil, 309 $\times 248$. Museum of New Zealand Te Papa Rita Angus Estate

In the sketch of her standing, Angus shows herself standing more firmly and easily, with her legs slightly apart and her gaze direct. There are no hands and feet, emphasising the torso. The portraits examine the physical attributes of being female. They show, despite the miscarriage, the beginning of the artist's realisation of her own "perfection and vitality". Angus writes to Lilburn at this time: "I want to tell you this that I do not despise my body. That my body belongs to me. This is to me important because no man has the right to despise my body." The strong shading around the figures suggests vibrancy and a redirection of love for her lost child into self and into herself as artist/creator.

Angus's nude sketches acknowledge an undeniable sexual and maternal function: her breasts and hips. These are stark references to the childbearing function that makes her a woman and are an irremovable part of her image even if she has no child. Outlined by shadow, the nudes appear like statues, goddess-like, removed. But the nude remains a sexual body. Importantly, Adams' study of the Madonna's use as feminist symbol does not preclude sexuality: "the Madonna can be a powerful figure for certain writers of [the Victorian]

period because of their radical understanding of virginity - psychic, social, and even sexual" (my italics). Not only is the Madonna made multi-faceted; she can be tailored to suit individual concerns. Lloyd identifies the standing nudes as studies of a statue of the Egyptian priestess Imeret-Nebe, with whom Angus "fused her body and identity". The priestess is chaste, virginal, dedicated to her god. Angus is likewise dedicated to her sacred duty to paint.

Angus's view of the sanctity of her role as an artist develops out of her new body image. The purpose of "quietly reclaiming [her] virginity" was "to serve the arts". She writes to Lilburn in April 1943, "as a high priestess, I learn my duty, to cause no pain to others, to accept myself as I am, to be responsible to myself and to my works, which is greater than I am. Living simply, trusting, and speaking the truth, to live up to my history of women". In late 1942, she describes herself as living a "moderate life", "alone in my monastery". Adams argues that the Madonna can be read as more than a tool of patriarchy to subordinate women to chaste, passive roles. She repositions the Madonna's virginity, and its significance for women who try to emulate it, in the words of nineteenth-century women's rights activist Margaret Fuller: "virginity is primarily a matter of self-intactness; the virgin state is 'self-subsistence in its two forms of self-reliance and self impulse'". This "self-intactness" leads to "self-expansion: woman as virgin can make her life beautiful, powerful, and complete, achieving the perfection God requires of every species and every soul", a sense of completeness that Angus's nudes also convey.

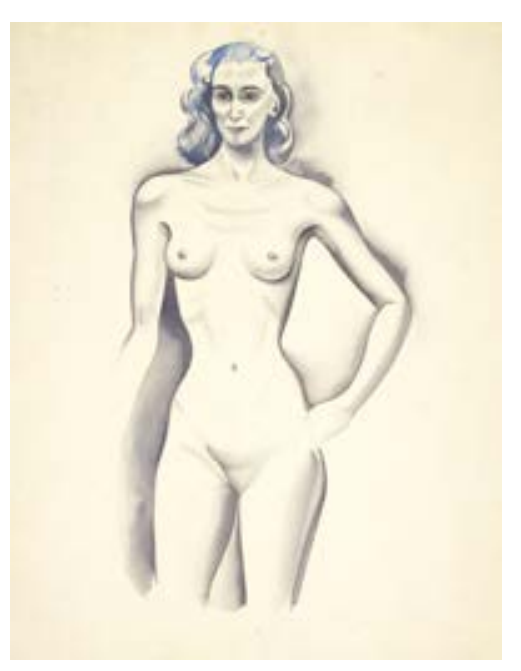

Rita Angus. Grisaille nude self portrait (standing) (c. 1942). Wash, $293 \times 224$. Museum of New Zealand Te Papa Tongarewa, TMP-001460 on loan from the Rito Angus Estate 
Nude self-portraits of women in the 1940 s are scarce, making Angus's excursion into the field of nude self-portraiture bold and experimental. One other example is Australian artist Freda Robertshaw's Standing nude (self portrait) (1944). While the reflection in the mirror behind her suggests sensuality, Robertshaw's stance in the foreground is confident and unselfconscious.

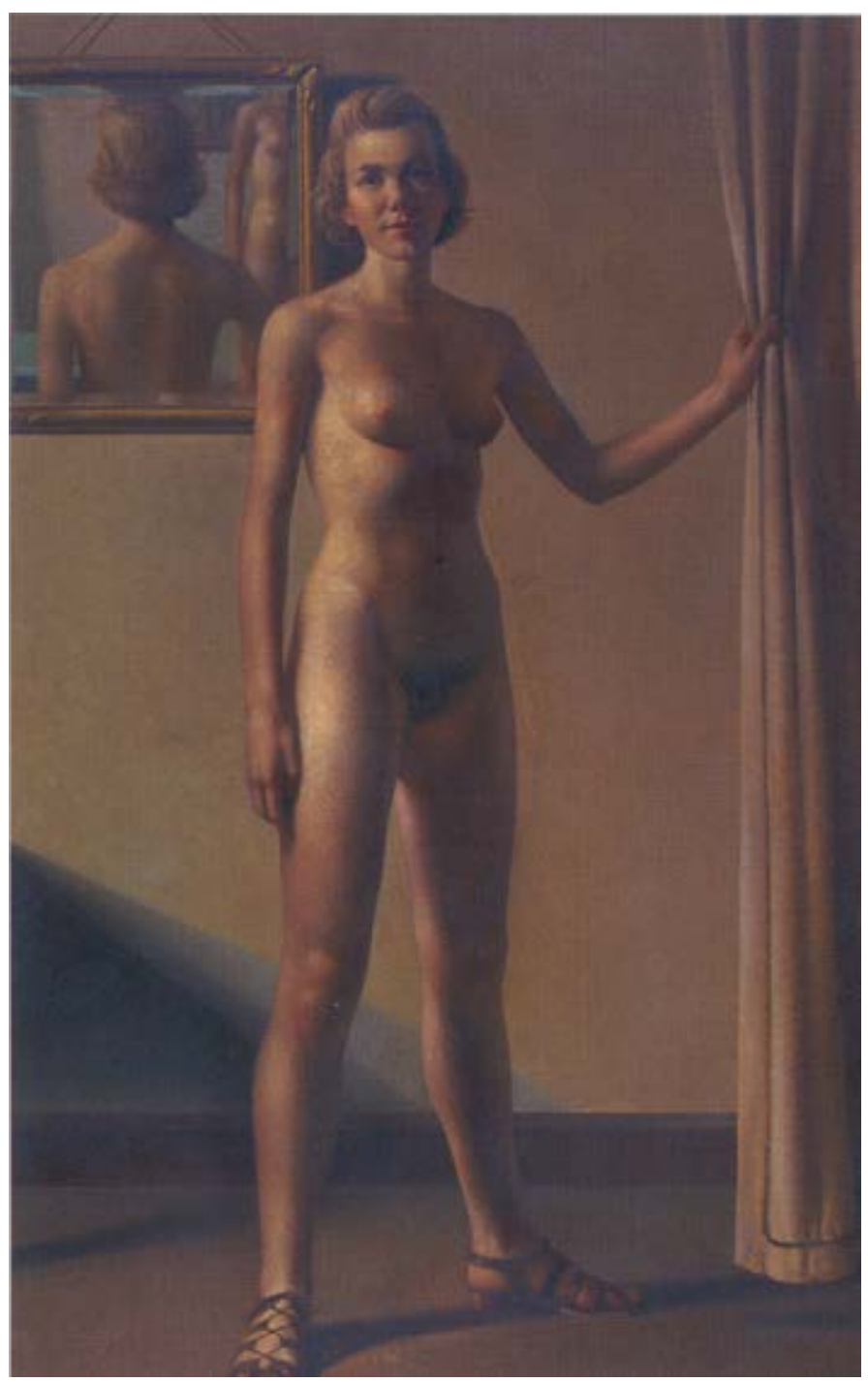

Freda Robertshaw. Standing Nude (1944). Oil on board, $1100 \times 690$. Cruthers Collection of Women's Art, University of Western Australia, CCWA 409
Like Angus, Robertshaw creates an image of herself nude in which she is gazer, both as artist and at the self in the mirror. Robertshaw's portrait has a feeling of life with the curtain being drawn to reveal a spectacle, and the artist still wearing her sandals as though she has briefly slipped her dress over her head. The painting has caught the moment, whereas Angus's is completely outside the moment. The mirror into which the artist looks to draw herself is implied, not seen, highlighting the separateness of Angus's body. Angus proclaims celibacy following her miscarriage. Her nude sketches express this as an acceptance of her body, and her own sense of completeness.

Lilburn rejected Angus's wish for another child and continuing intimacy. However, Angus gained a new motherhood - to her painting. In a letter to Lilburn in 1943, a poem, "Embryo", alludes to Angus's transition from carnal love to love that is pure and spiritual, and also distant.

\section{I look toward the sun}

And receive warmth and kindliness,

Naked and unashamed.

The Lord said unto Moses,

The adulteress shall surely be put to death!

Christ said unto her,

Thy sins are forgiven,

Thy faith hath saved thee, go in peace.

Cruelty and benevolence.

A vessel of Purity

The Madonna of Lovers,

And not Aphrodite, Goddess of Love.

Perfection.

Through my body and my mind,

Enmity to Love.

"Embryo" refers to the miscarriage and makes use of the language of motherhood that Angus was beginning to apply to her painting expressing physical pregnancy as analogous to creative fertility:

"I felt the life continuity in me when I was pregnant, and an exaltation because the child was yours. I wanted the life continuity to go on. Can you understand why I wanted another child. I am amazed the life continuity does go on in a different way. Everything I paint has the sense of being alive." 
In 1948, Angus stated that she had come to think of her miscarried child as a boy, and that if the boy "had been a girl she could have lived, hence the painting of Sun Goddesses". Moving on from the nudes, Angus rewrites the death of the Christ child, and her own child, by creating "living" portraits. The goddess portraits stand as works of peace and love, mothers to a new world. She wrote in 1943, "I imagine that had I not been born an artist, but a Madonna, married at 22, could have at least six children now, it overwhelms me".

In April 1942, Angus attended a rehearsal of Lilburn's composition Magnificat and Nunc Dimmitis in Christchurch Cathedral. Lloyd notes that as Angus listened to choristers singing the story of the Virgin Mary, "her revelation was this: Douglas Lilburn was exalting a 'New Madonna' and that woman was Rita Angus herself." In November that same year, Angus was to refer to the moment as her "'revelation"" in the Cathedral. In August 1944, in a letter in which she mourned the dead while those in the streets were celebrating the Liberation of Paris, she reminds Lilburn that "[w]hen you composed the Magnificat you exalted a new Madonna". In September, she describes this woman as herself, "a woman pacifist". The Madonna looks down towards her child. Like the nudes, Angus's goddesses, New Madonnas, look out, across.

\section{GODDESSES: A NEW MADONNA}

From 1945-1951 Angus painted three major goddess works, her paintings Rutu (1945-1951), A Goddess of Mercy (1945-1947), and Sun Goddess (1946-1949). Lloyd provides these dates of composition, stating that Rutu is the first Sun Goddess. The goddesses represent engagement with love in the post-war world, creating realms of peace and healing. In the early 1940s Angus asks for "in a few years, a calm joyful, Franciscan world of flowers and trees?" This is the world of the goddesses. In a review of a 1951 London exhibition of New Zealand painters, English art critic Maurice Collis called Rutu a "saintly vision of a Siennese Madonna". Angus clarifies: "Rutu may resemble a Siennese Madonna, she is also her own age, as well as ahead of her era."

The goddesses are new women, removed from the domestic landscape of the home, holding flowers rather than babies. Rutu sits on a throne before the sea, A Goddess of Mercy stands before farmed hills with a root system forming a halo around her head, and Sun Goddess is ensconced in wildflowers.

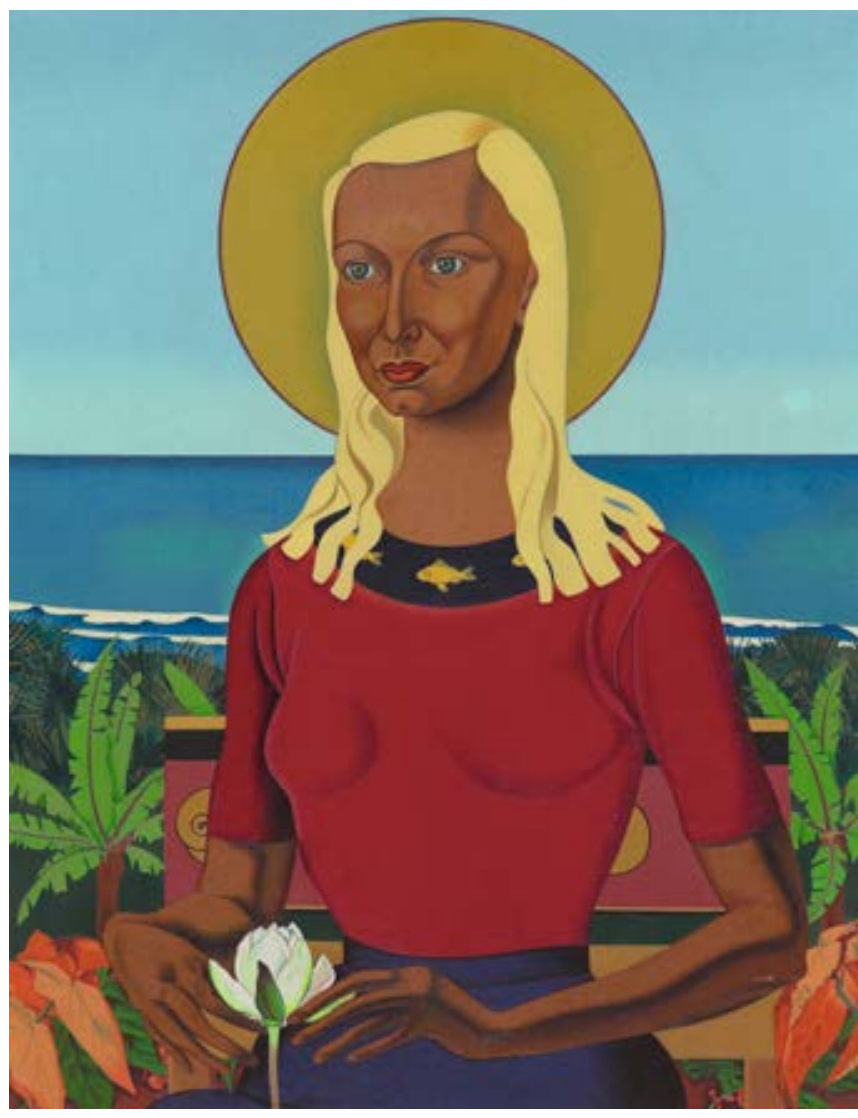

Rita Angus. Rutu (1951). Oil on canvas, $707 \times 548$. Museum of New Zealand Te Papa Tongarewa, purchased 1992 with New Zealand Lottery Grants Board funds, 1992-0025-1

While these are intensely reproductive landscapes, with spring and summer flowers and ploughed fields, the goddesses are quiet, sacrosacnt. Angus's wide landscapes highlight that despite their accentuated figures, the landscape as woman's body, the red berries amongst the leaves and red lips of Rutu, the goddesses are alone, self-sufficient. What is more, her interpretation of the goddesses as her children emphasises, through the portraits, reproduction as the work of a woman's (artist's) hands. Adams writes that Fuller considered the Madonna "a powerful symbol of the female artist, miraculously producing books, or 'virgin births,' with no man's aid." Like A Goddess of Mercy, in which the hills on each side of the goddess might form a woman's breasts, Rutu has sexual possibilities - the slow blush creeping 
into the stem and petals of the waterlily, her accentuated figure, the red berries hidden amongst the leaves, and her red lips. Despite this, the goddesses are alone and self-sufficient. Considering the Culture of Love in nineteenth-century literature and art, Stephen Kern notes that because a woman's hand passes from father to husband, control over hands shows power, while open hands indicate helplessness. The hands of these twentieth-century goddesses are all occupied. The flowers that they hold are full and blooming.

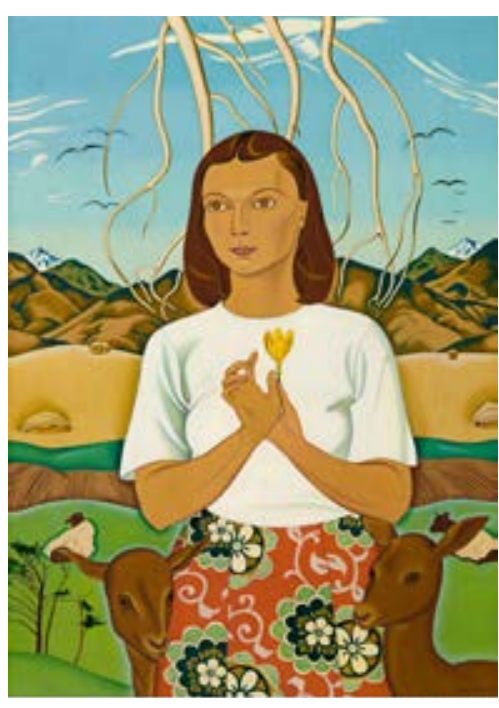

Rita Angus. A Goddess of Mercy (1945-1947). Oil on canvas, 866 $\times 611$. Collection of Christchurch purchased 1956, 69/75

While Rutu is still labelled as a self-portrait where it hangs in Te Papa in Wellington, Lloyd refutes this, and I agree that to view Rutu solely as a self-portrait would be limiting, particularly in regard to the narrative of the painting as child and herself as "mother" that Angus unfolds in her letters to Lilburn. However, Angus was known to play with her own image. A clear example is the watercolour sketch Fairhaired woman with bird (1951?). Angus literally inserts herself into the goddess's pose, half profile, her gaze turned slightly to the viewer's left. Her lilac eyes have an exotic, oriental tilt, echoing the soft tones of the sky, the bird sitting on her hand, and the pink cloth over her arm. What is more, she is half nude, her breasts exposed. Lloyd states that the work is likely the one that Angus was referring to when she wrote from

her parents' house where she was recovering from a breakdown in 1949 I've made a note of another 'Goddess.' It will be a while yet before I am ready to continue. She is classical. The setting is of the landscape around this district, (extending a few miles) hills and trees.

Angus often described herself as "classical". At this juncture, the goddess might be associated with a reassessment of self, with healing In "Embryo" (1943), Angus states:

I look toward the sun,

And receive warmth and kindliness,

Naked and unashamed.

The fair-haired woman is not simply an act of fantasy, but presents to the world the image that the artist herself sees, one that is beautiful, admirable, whose body is not a source of shame from an illegitimate pregnancy, but exaltation. In the same year as the poem, a sketch in a letter depicts another naked Angus with blonde hair, reaching out above her head for the sun.

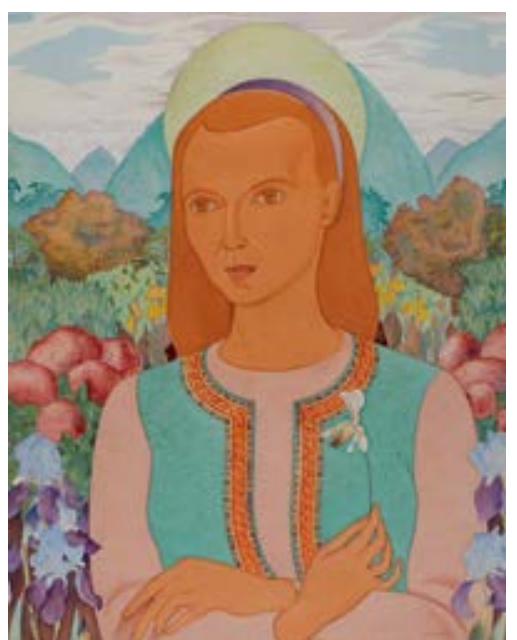

Rita Angus. Sun Goddess (1946-1949). Watercolour $532 \times 420$. Private Collection

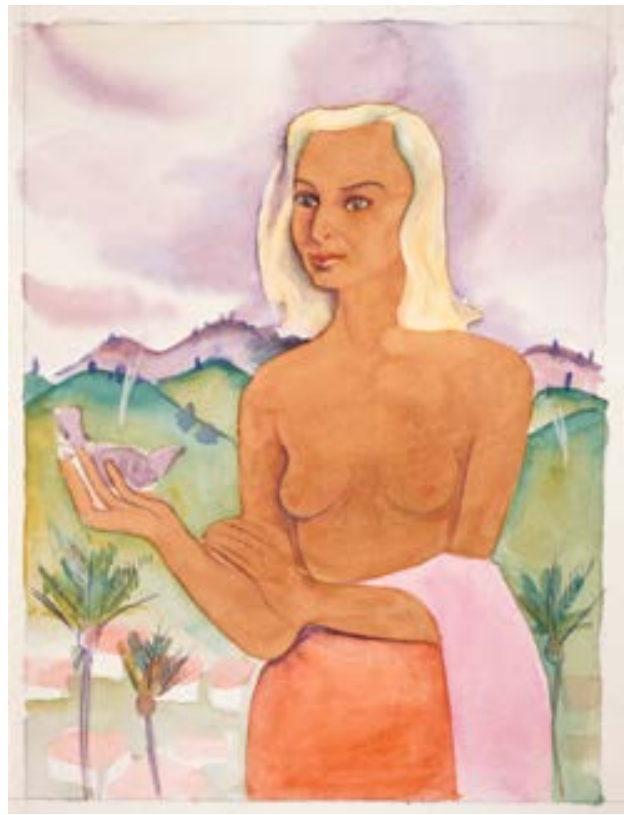

Rita Angus. Fair-haired woman with bird. Selfportrait (1951?). Watercolour on card, $150 \times 112$. Alexander Turnbull Library, Wellington, E-439-f-010 


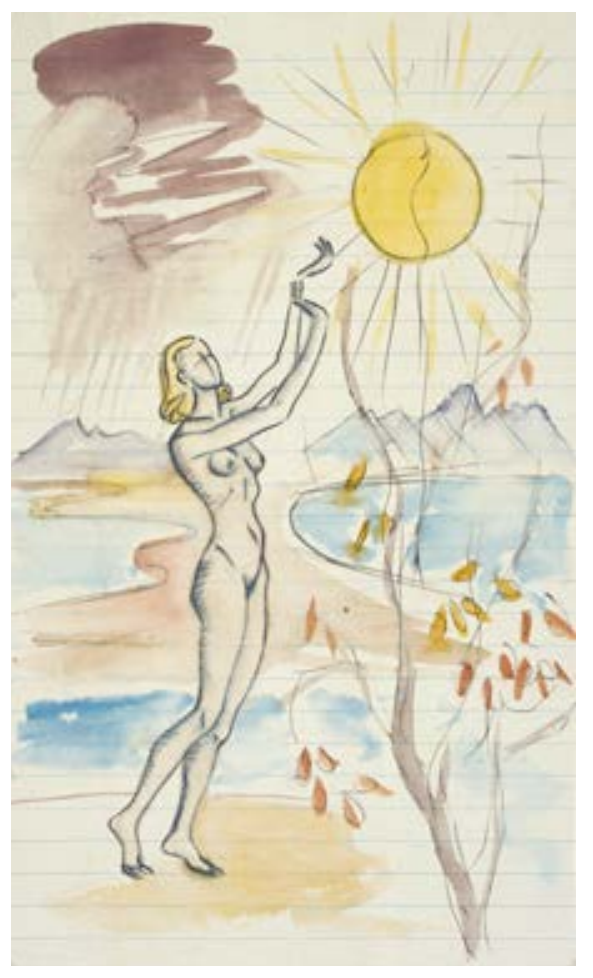

Rita Angus. Untitled. Ink and watercolour sketch on lined paper,

Library, Wellington, A-354-024
The naked woman under the sun recalls a verse in Revelation, that "a woman clothed with the sun" will initiate the second coming (12:1-12:2). The woman of Revelation, pregnant and giving birth to a child can be interpreted as Mary, Mother of God, and fits with Angus's possession of her image as Madonna of a second coming of worldwide peace following the war. In the same letter as the sketch, Angus recounts a dream she had of Lilburn in which he kissed her, and which made her happy because it portended a peaceful relationship: "There was no desire in your action, you turned me round, kissed me, and said, 'You are a part of my life, and I am a part of yours,' I didn't work that day, but lay in the sun." In this letter Angus reiterated what would be a tenet of her mythology: "I know myself through a knowledge of my own body".

A later goddess image, Figure at Sumner (c. 1949), evokes Mary's image directly in showing a woman in a blue habit and veil standing on a beach. From 1943, Angus was living and working in a cottage at Clifton, up on the hilltop above Sumner Beach. While not labelled as a self-portrait, the woman has blonde hair like Angus, and blue eyes show underneath her veil. Her halo, above the water, gives the impression of a rising sun, evoking Mary as Stella Maris, Our Lady, Star of the Sea. An oil portrait, Young girl holding beads (c. 1950), in which a girl holds a rosary before a landscape of trees makes further use of the Marian image. The girl is dressed in blue with a translucent dark veil over her brown hair, the clouds in the sky following the silhouette of her head. Like Angus's major goddesses, these two appear alone. While obviously feminine, and thus set apart from Angus's earlier Self-Portrait (1936-1937) in trench coat, something similar is played out. Angus sets a stage on which she is self-sufficient, as an artist, as a celibate New Madonna. According to Fuller, virginity "allows woman to be a powerful solitary figure who is 'betrothed to the Sun,' clothed with the sun,

shining with divine glory." These two pictures exemplify a mix of Marian and New Madonna divinity.
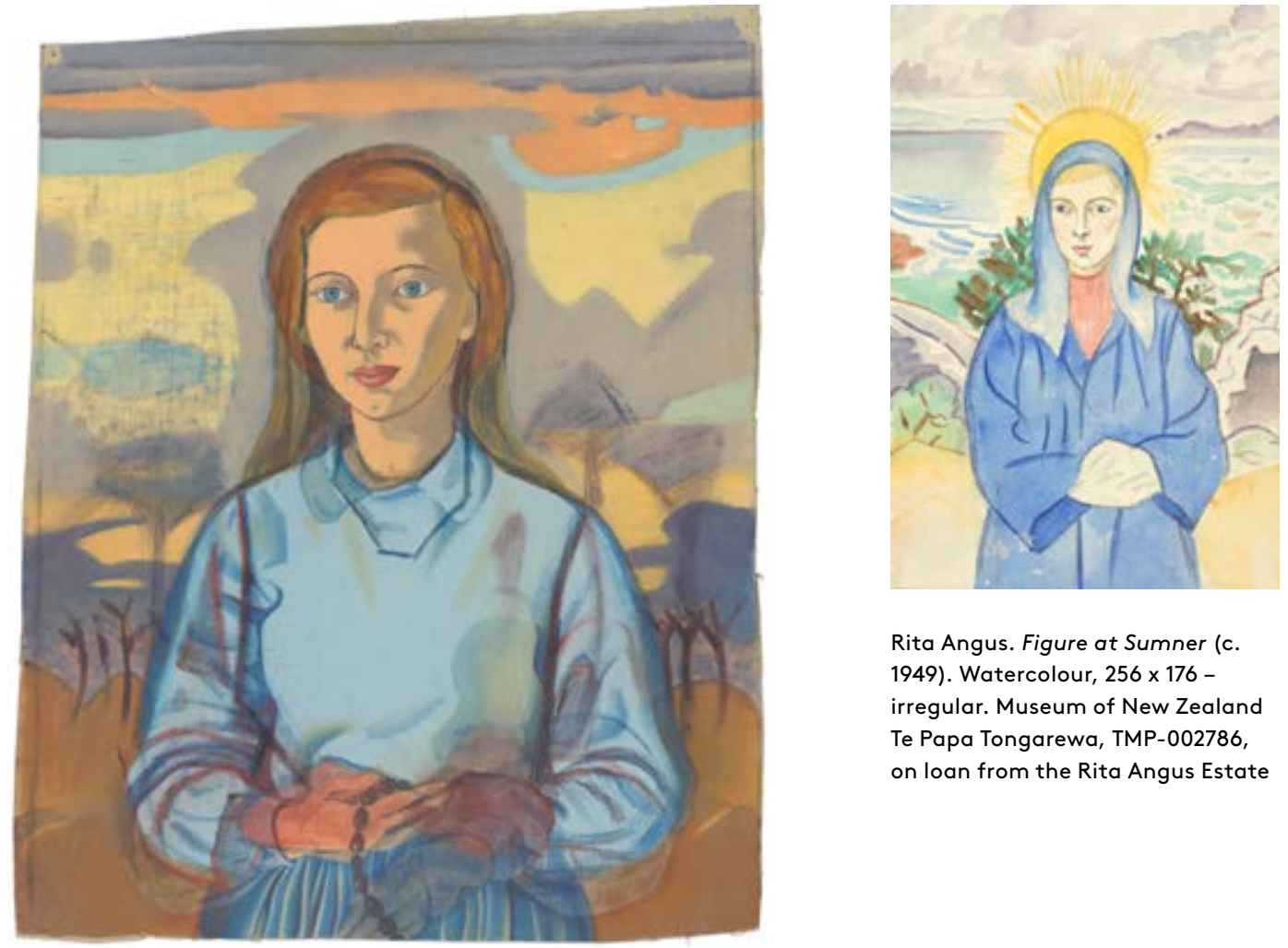

Rita Angus. Figure at Sumner 1949). Watercolour, $256 \times 176-$ irregular. Museum of New Zealand Te Papa Tongarewa, TMP-002786, on loan from the Rita Angus Estate 


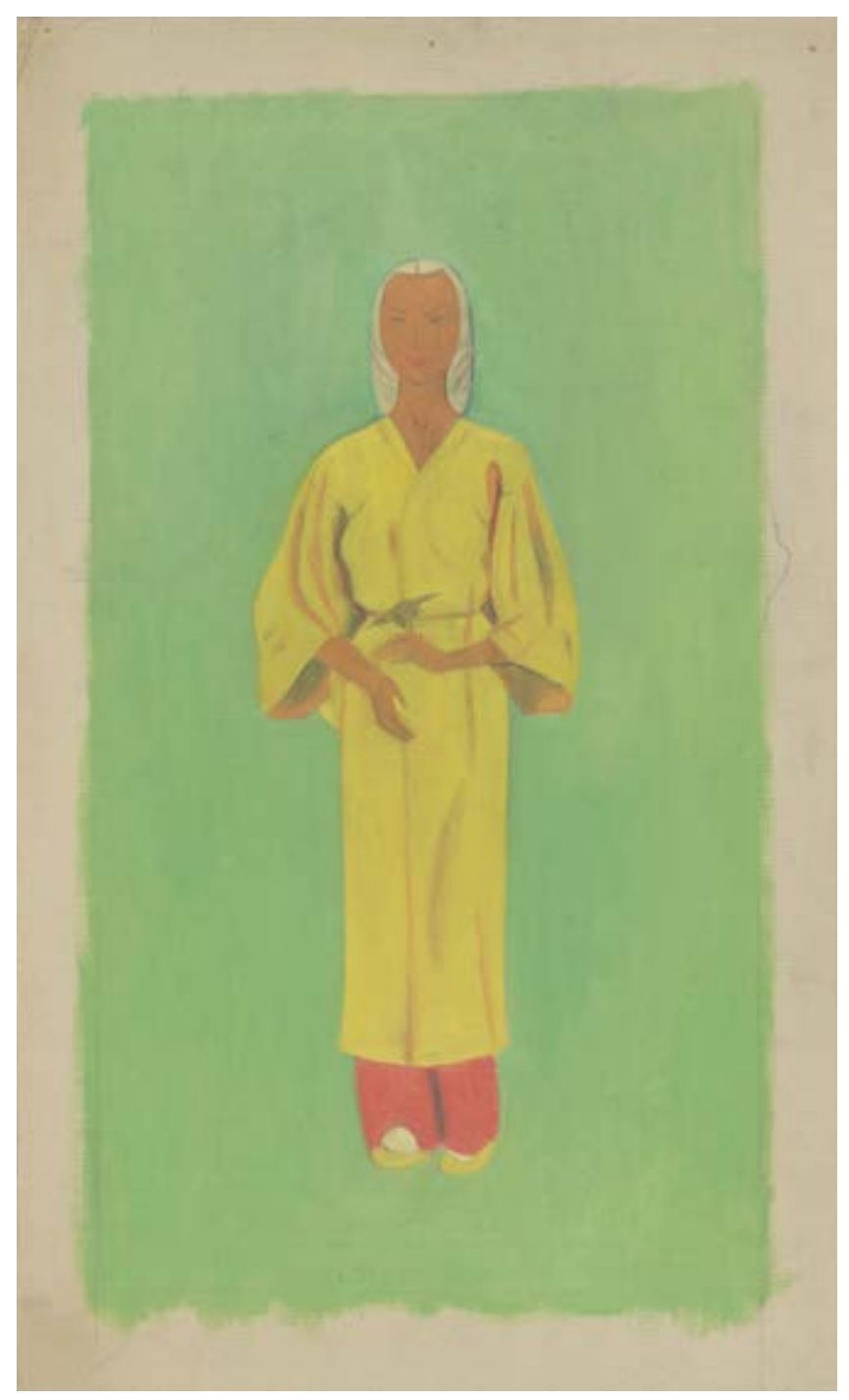

An unfinished portrait, Self-portrait in Oriental dress (c. 1946) extends the qualities of the Madonna to non-Christian imagery. This partially painted woman is dark skinned, wearing a green oriental robe with red trousers and green shoes. Her hands are held in front of her in a gesture that evokes Angus's Rutu and A Goddess of Mercy, and a bird rests on her upper hand. Trevelyan draws attention to an exhibition of Chinese art that toured New Zealand in 1937, curated by Captain George Humphreys-Davies for the National Art Gallery and Dominion Museum. The exhibition contained a bronze figure of the Buddhist goddess of mercy and compassion, Kuan Yin.
Trevelyan draws a comparison between Kuan Yin and Angus's Goddess of Mercy. She writes that:

[u]sually depicted as a barefoot, gracious woman, her palm exposed in a gesture of benediction, and often associated with a willow branch, Kuan Yin is a virgin goddess who protects women, offers a religious life as an alternative to marriage, and grants children to those who desire them. She would have been an immensely attractive figure to Rita.

In Angus's self-portrait, this "gesture of benediction" can be seen, with the hand on the left lowered and the hand on the right drawn overtop, a reversal of but very similar to a eighteenth-century statue of Guanyin (an alternative spelling) held by the Auckland Museum. Combining virginity and motherhood, this oriental goddess would have appealed to Angus's ideals of world peace and inclusivity.
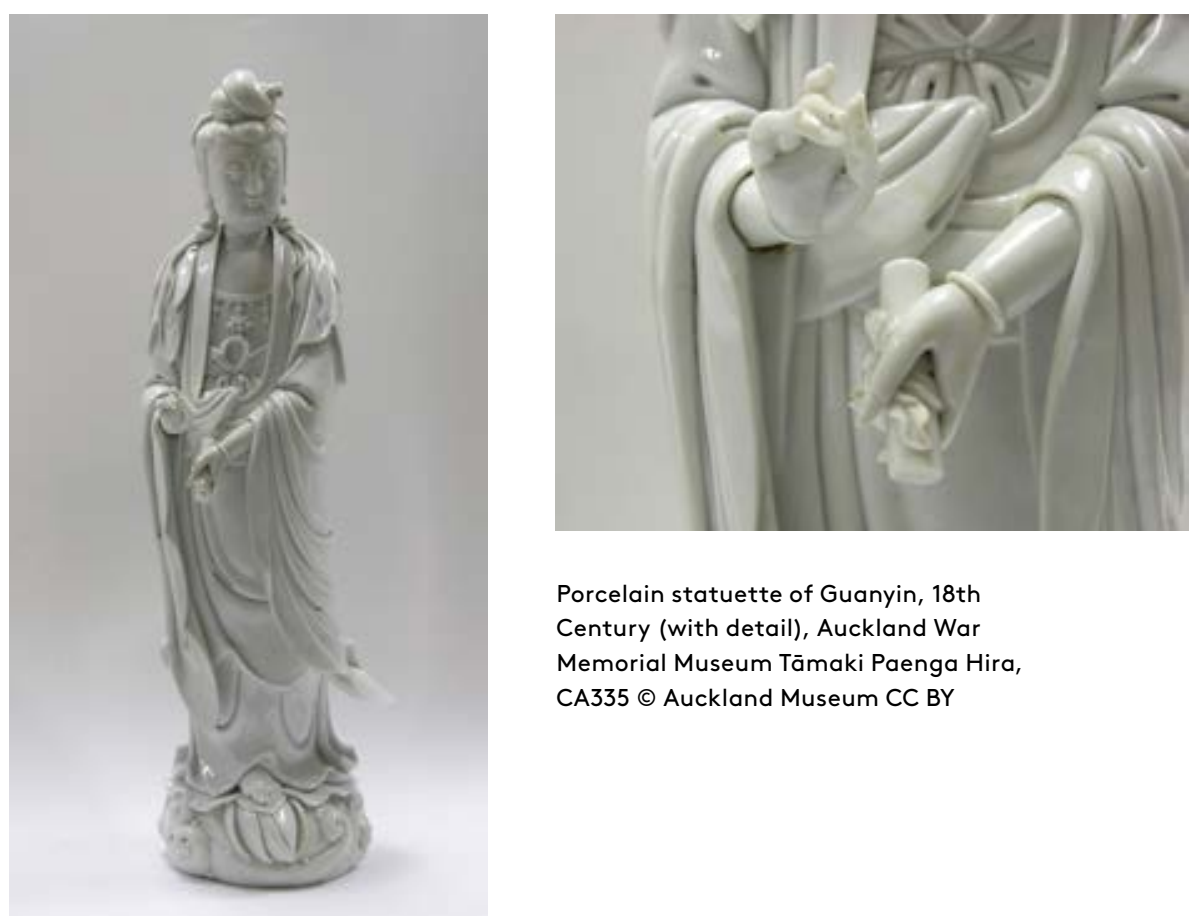

Porcelain statuette of Guanyin, 18th Century (with detail), Auckland War Memorial Museum Tămaki Paenga Hira, CA335 $\odot$ Auckland Museum CC BY 
For Angus as artist, creation becomes an expressly female process. Her description of her painting uses the vocabulary of motherhood: "My major works are now in embryo" and "Last Friday evening I brought forth a portrait [...] I am spending my confinement quietly in the garden". In Luke 2:7, Mary "brought forth her firstborn son". "[B]rought forth" also describes the creation recorded in the Bible in Genesis, when "the earth brought forth grass" and "the waters brought forth" new creatures $(1: 12,21)$. Further, in Leviticus $25: 55$ the Lord "brought forth" His chosen people from Egypt. All these actions represent new beginnings. Angus evokes Mary directly to describe the creative process:

The joy of creative conception,

I know not pain or sorrow

Within leaps, our child of beauty,

Of charity, intelligence,

The Holy Ghost fills within me,

Gently soothes my mind and body.

The repositioning of the female divine within Angus's own body, both as Mary and in herself-portrait as goddess, is a statement of self-sufficiency.

Finally, Figure with Rose: Mozart Quartet No. 21 (c. 1948-1951) provides further evidence of the importance of Angus's celibate self-image to her independence. The face of this naked goddess is not Angus's, yet the body bears similarities to her first standing nude: the crease of flesh on her inner left thigh, and her accentuated waist and full breasts, as if the nude woman is transformed into goddess. Rising behind her are feathery wings, with a moon or halo behind her head. The image is mainly blue, apart from the pink rose in the woman's hand which might be associated with new life. A yellowish sheen creeps up to her waist and covers her lower arms, falling like sunlight on her hair, parts of her face, and the roundest parts of her breasts. The woman is encased in the universe. The light could be the rising sun, while the pinpricks of white in the blue next to her body appear as stars. She is cosmic creating a sacred universe - a cyclic wholeness. That the painting is named for a piece of music accords with the practice Angus describes of sketching to music, in turn associated with her connection to Lilburn. Trevelyan states: "Increasingly, [Angus] would come to see her and Lilburn's art as the testament to their relationship".
Representing the composer and the painter drawn together, the picture expresses their relationship in a symbolic rather than a physical sense: this angel/goddess is the product of both disciplines.

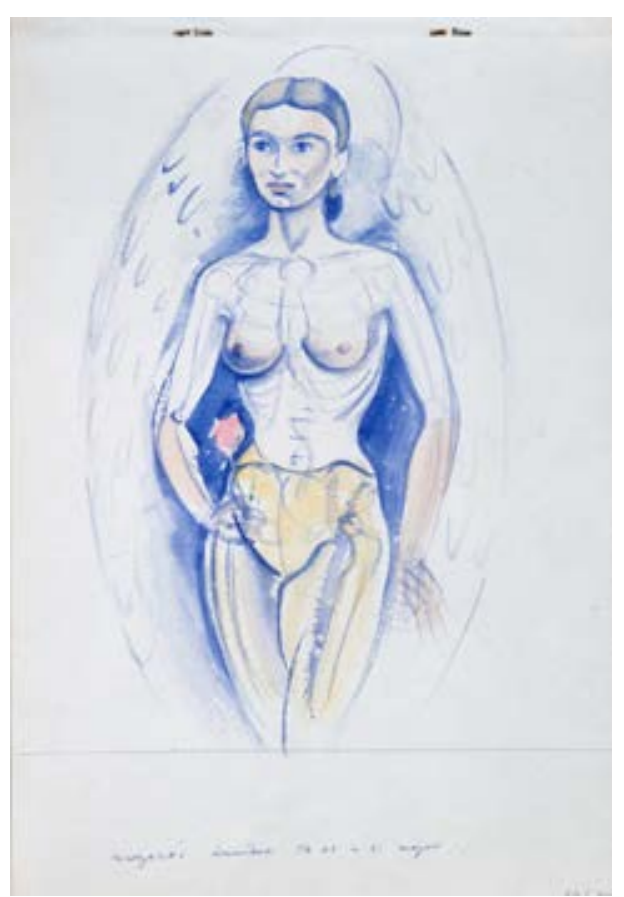

Rita Angus. Figure with rose, Mozart Quartet no 21 in D Major (1948-1951) Watercolour, $270 \times 184$ Wexander Turnbull Library,

Angus's art becomes a medium to validate who she is as a woman and an artist, exploring who she is as she transitions from the trench coat model towards a new model of female independence. In 1947, Angus tells Lilburn that the goddesses, these sacred divinities,

"don't mind being illegitimate". The crafting of a "world of my own", she states, is a result of these "last five years of celibacy". Her renegotiation of the roles of a loving female, wife and mother, into an independent, powerful image, representing herself as New Madonna, high priestess, and goddess, offers an alternative to physical love - both in the context of a child and a partner. 


\section{REFERENCES}

Adams, Kimberley VanEsveld. "Feminine Godhead, Feminist Symbol: The Madonna in George Eliot, Ludwig Feuerbach, Anna Jameson, and Margaret Fuller." Journal of Feminist Studie in Religion 12, no. 1 (Spring, 1996): 41-70.

Adams, Kimberley VanEsveld. Our Lady of Victorian Feminism: Our Lady in the Work of Anna Jameson, Margaret Fuller, and George Eliot. Athens: Ohio University Press, 2001.

'Alexa'. "Women and Divorce Reform - An Opportunity for Feminists." Woman To-Day, Jun 1, 1937: 62.

Brownson, Ron. "Symbolism and the Generation of Meaning in Rita Angus's Painting." In Rit Angus, edited by Luit H. Bieringa, 79-88. Wellington: National Art Gallery, 1982.

Eve, Alys, ed. The Modern Girl Around the World: Consumption, Modernity, and Globalization. Durham: Duke University Press, 2008

Kern, Stephen. The Culture of Love: Victorians to Moderns. Cambridge: Harvard University Press, 1992.

'King James Bible.' King James Bible Online. Accessed January 16, 2019. https://www. kingjamesbibleonline.org/

Lilburn, Douglas. Inward Correspondence - Rita Angus. MS-Papers-7623-049 to MS-
Papers-7623-091. Alexander Turnbull Library, Wellington.

Lloyd, Bronwyn. "Daemons and Dream Children: The Secret Lives of Rita Angus's Symbolic Portraits." PhD Thesis, University of Auckland, 2009.

Lloyd, Bronwyn. "The Goddesses: Rita Angus's Painted Emissaries of Peace." In Rita Angus: Lif and Vision, edited by William McAloon and Jill Trevelyan, 109-113. Wellington: Te Papa Press, 2008.

Niehoff, Pamela. "The New Woman and the Politics of Identity." Strange Women: Essays in Art and Gender, edited by Jeanette Hoorn, 38-52. Melbourne: Melbourne University Press, 1994.

Quirk, V. "Which Type Are You?" Ladies' Mirror 3, no. 4 (1 October 1924): 27. Accessed January 16, 2019. https://paperspast.natlib.govt.nz/ periodicals/LADMI19241001.2.26

Souter, Gerry. Frida Kahlo: Beneath the Mirror New York: Parkstone Press, 2005

Trevelyan, Jill. Rita Angus: An Artist's Life. Wellington: Te Papa Press, 2008.

Wadman, Howard, ed. Year Book of the Arts in New Zealand 1947, no. 3. Wellington: Harry $\mathrm{H}$. Tombs, 1947.

\section{ENDNOTES}

1 All artwork by Rita Angus is reproduced courtesy of the Angus estate.

2 "Alexa", "Women and Divorce Reform" Woman To-Day, June 1, 1937, p.62.

3 V. Quirk, "Which Type Are You?" Ladies' Mirror 3, no. 4 (1 October 1924), p. 27.

4 Pamela Niehoff, "The New Woman", in Jeanette Hoorn, ed., Strange Women, Melbourne, 1994, pp. 42-43.

5 Niehoff, "The New Woman", pp. 43, 45.

6 Jill Trevelyan, Rita Angus: An Artist's Life, Wellington, 2008 p. 174

7 Trevelyan, Rita Angus, pp. 139, 190

8 Bronwyn Lloyd, "Daemons and Dream Children", PhD thesis, University of Auckland p. 158.

9 Trevelyan, p. 128

10 Lloyd, "Daemons", p. 105.

11 Angus to Lilburn, 11 July 1942, Douglas Lilburn - Inward Correspondence, MS-P-7623-051, Alexander Turnbull Library (ATL), Wellington

12 Angus to Lilburn, 11 July 1942, MS-P-7623-051 ATL.

13 Kimberley VanEsveld Adams, "Feminine Godhead, Feminist Symbol", Journal of Feminist Studies in Religion 12, no. 1 (1996), p.

14 Lloyd, "Daemons," p. 105.

15 Angus to Lilburn, 12 June 1942, MS-P-7623 050, ATL.

16 Angus to Lilburn, 16 April 1943, MS-P-7623 052, ATL.

17 Angus to Lilburn, 8 November 1942, MS-P7623-051, ATL.

18 Adams, "Feminine Godhead", pp. 58-59.

19 Trevelyan, p. 120.

20 "[A]s I shall not sleep again with a man $\mathrm{my}$ eputation is nothing, what is a reputation, I've never seen one." Angus to Lilburn, undated, 1942, MS-P-7623-050, ATL.

21 Angus to Lilburn, August 20, 1943, MS-P-7623053, ATL.

22 Angus to Lilburn, July 1942, MS-P-7623-051 ATL.

23 Angus to Lilburn, 15 January 1948, MS-P-7623 064, ATL.
24 Angus to Lilburn, 23 February 1944, MS-P7623-054, ATL.

25 Angus to Lilburn, 29 July 1943, MS-P-7623-052, ATL.

26 Lloyd, "Daemons", p. 108.

27 Angus to Lilburn, 8 November 1942, MS-P7623-051, ATL, cited in Lloyd, "Daemons," 107.

28 Angus to Lilburn, 24 August 1944, MS-P-7623056; 24 [Sept] 1944, MS-P-7623-056, ATL.

29 Lloyd, "Daemons", pp. 5-6.

30 Angus to Lilburn, 14 June 1944, MS-P-7623 055, ATL.

31 Cited in Lloyd, 'Daemons", p. 236.

32 Angus to Lilburn, 3 March 1955, MS-P-7623082, ATL.

33 Kimberley VanEsveld Adams, Our Lady of Victorian Feminism, Athens, 2001, p. 1.

34 Stephen Kern, Culture of Love, Cambridge 1992, pp. 70-71.

35 Lloyd, "Daemons", p. 16

36 Angus to Lilburn, 22 September 1950, MS-P7623-070, ATL. Lloyd, “Daemons", p. 228.

37 Angus to Lilburn, 24 February 1947, MS-P7623-062, ATL.

38 Angus to Lilburn, August 20, 1943, MS-P-7623 053, ATL.

39 Angus to Lilburn, April 19, 1943. MS-P-7623 052, ATL.

40 Angus to Lilburn, April 19, 1943, MS-P-7623 052, ATL.

41 Trevelyan, p. 142.

42 Adams, "Feminine Godhead", p. 64

43 Trevelyan, p. 369, n. 74; p. 383, n. 14

44 Trevelyan, p. 193.

45 Angus to Lilburn, 14 June 1944, MS-P-7623 055; 5 April 1943, MS-P-7623-052, ATL.

46 "King James Bible."

47 Angus to Lilburn, 23 February 1944, MS-P7623-054, ATL.

48 Angus to Lilburn, April 23, 1954, MS-P-7623078, ATL.

49 Trevelyan, p. 130

50 Angus to Lilburn, May 28, 1947, MS-P-7623062, ATL.

51 Angus to Lilburn, February 24, 1947, MS-P7623-062, ATL. 